\title{
Markers of intestinal inflammation in patients with ankylosing spondylitis: a pilot study
}

\author{
Franziska G Matzkies', Stephan R Targan², Dror Berel ${ }^{2}$, Carol J Landers ${ }^{2}$, John D Reveille ${ }^{3}$, Dermot PB McGovern ${ }^{2,4}$ \\ and Michael $\mathrm{H}$ Weisman ${ }^{5^{*}}$
}

\begin{abstract}
Introduction: Inflammatory bowel disease (IBD) and ankylosing spondylitis (AS) are similar chronic inflammatory diseases whose definitive etiology is unknown. Following recent clinical and genetic evidence supporting an intertwined pathogenic relationship, we conducted a pilot study to measure fecal calprotectin (FCAL) and IBD-related serologies in AS patients.
\end{abstract}

Methods: Consecutive AS patients were recruited from a long-term prospectively collected longitudinal AS cohort at Cedars-Sinai Medical Center. Controls were recruited from Cedars-Sinai Medical Center employees or spouses of patients with AS. Sera were tested by ELISA for IBD-associated serologies (antineutrophil cytoplasmic antibodies (ANCA), anti-Saccharomyces cerevisiae antibody IgG and IgA, anti-I2, anti-OmpC, and anti-CBir1). The Bath Ankylosing Spondylitis Disease Activity Index, the Bath Ankylosing Spondylitis Functional Index, and the Bath Ankylosing Spondylitis Radiology Index were completed for AS patients.

Results: A total of 81 subjects (39 AS patients and 42 controls) were included for analysis. The average age of AS patients was 47 years and the average disease duration was 22 years. AS patients were predominantly male; $76 \%$ were HLA-B27-positive. Median fCAL levels were $42 \mu \mathrm{g} / \mathrm{g}$ and $17 \mu \mathrm{g} / \mathrm{g}$ in the AS group and controls, respectively $(P<0.001)$. When using the manufacturer's recommended cutoff value for positivity of $50 \mu \mathrm{g} / \mathrm{g}$, stool samples of $41 \%$ of AS patients and $10 \%$ of controls were positive for fCAL $(P=0.0016)$. With the exception of ANCA, there were no significant differences in antibody levels between patients and controls. Median ANCA was 6.9 ELISA units in AS patients and 4.3 ELISA units in the controls. Among AS patients stratified by fCAL level, there were statistically significant differences between patients and controls for multiple IBD-associated antibodies.

Conclusion: Calprotectin levels were elevated in $41 \%$ of patients with AS with a cutoff value for positivity of $50 \mathrm{\mu g} / \mathrm{g}$. fCAL-positive AS patients displayed higher medians of most IBD-specific antibodies when compared with healthy controls or fCAL-negative AS patients. Further studies are needed to determine whether fCAL can be used to identify and characterize a subgroup of AS patients whose disease might be driven by subclinical bowel inflammation.

\section{Introduction}

Inflammatory bowel disease (IBD) and ankylosing spondylitis (AS) are similar chronic inflammatory diseases whose definitive etiology is unknown. Although both appear to be distinct and well-defined phenotypes, there is increasing clinical and genetic evidence supporting an intertwined pathogenic relationship [1]. Clinically, 5 to $10 \%$ of all patients with AS have concurrent IBD [2]. In patients with

\footnotetext{
* Correspondence: Michael.Weisman@cshs.org

${ }^{5}$ Division of Rheumatology, Cedars-Sinai Medical Center, 8700 Beverly

Boulevard, Becker B-131, Los Angeles, CA 90048, USA

Full list of author information is available at the end of the article
}

AS without specific gastrointestinal complaints, macroscopic gut inflammation resembling Crohn's disease has been observed in 25 to $50 \%$ of all patients by colonoscopy [3]. Histological analyses of gut biopsies in AS patients have observed evidence of microscopic gut inflammation even more frequently with a prevalence of 50 to $60 \%$ [4-7]. Alternatively, sacroiliac changes similar to those seen in AS have been noted in 10 to $20 \%$ of patients with the primary diagnosis of IBD and 7 to $12 \%$ of IBD patients carry the concomitant diagnosis of AS [8].

The genetic susceptibility risk is high in both conditions [9-13] and recent studies with large and well-characterized

\section{Biomed Central}


cohorts support an important genetic overlap between AS and IBD. The Icelandic genealogy database has shown that AS and IBD have a strong elevated cross-risk ratio in firstdegree and second-degree relatives [14]. HLA-B27 contributes approximately one-half of the genetic risk for AS, and the prevalence of the HLA-B27 positivity in AS approaches $90 \%$ [15]. In studies of patients with IBD with associated spondylitis and sacroiliitis, the prevalence of HLA-B27 varies from 25 to $78 \%$ depending on the study [16]. In the absence of sacroiliitis, the prevalence of HLA$\mathrm{B} 27$ in IBD is not different from that in healthy controls (reviewed in [17]). Recently published large genome-wide association studies have identified multiple non-major histocompatibility complex susceptibility loci that provide additional evidence for a genetic overlap between Crohn's disease and AS. These loci include IL23R, STAT3, IL-12B, TNFSF15 and the intergenic region at chr1q32. The chr1q32 is located close to the $K I F 21 B$, a gene that encodes for kinesin motor proteins [18]. IL-23R, STAT3 and $I L-12 p 40$ all play an important role in the Th17 inflammatory pathway.

Mucosal dysregulation may be an important pathway linking genetic susceptibility to environmental triggers in both conditions. Patients with IBD and AS both have increased intestinal permeability as shown by the ${ }^{31} \mathrm{Cr}$-ethylenediamine tetraacetic acid resorption test [19]. Loss of tolerance to normal bowel flora as evidenced by an increase in circulating antibodies to certain bacterial antigens has been observed in IBD, including anti-Saccharomyces cerevisiae mannan antibodies (ASCA) [20], anti-Escherichia coli outer-membrane porin $\mathrm{C}(\mathrm{OmpC})$ and anti-CBir1 flagellin $\mathrm{AB}$ [21]. The same IBD-associated serologic markers present at a greater frequency and at a higher titer in AS patients compared with healthy controls, indicating a potential loss of tolerance to commensal bacteria similar to that observed in IBD patients [22-25].

Calprotectin is a neutrophil-derived protein that can be quantified in the feces and has become established as a marker of whole gut inflammation. The increase of fecal calprotectin (fCAL) seen in the stool of IBD patients is a direct result of increased neutrophil migration into the gut lumen across inflamed mucosa (as reviewed in [26]). In subjects with IBD, levels of fCAL correlate with endoscopic and histological degree of bowel inflammation $[27,28]$. Furthermore, fCAL has been successfully shown to predict relapses and detect pouchitis in patients with IBD and to consistently differentiate IBD from irritable bowel syndrome.

Although IBD is typically diagnosed by direct observation (colonoscopy) and confirmed with biopsy and histology, finding alternative ways to assess subclinical inflammation in a large cohort of patients would be beneficial for epidemiologic studies and continued long-term multi-disciplinary investigations into the relationship between these two diseases. To further address the question of subclinical bowel inflammation in AS patients, we measured fCAL combined with IBD-related serologies in this pilot exploratory study.

\section{Materials and methods \\ Patient selection}

Consecutive AS patients were recruited from our long-term prospectively collected longitudinal AS cohort at CedarsSinai Medical Center (CSMC) [29]. All patients were 18 years of age or older, supplied written consent, and met the modified New York criteria for AS [30] at the time of enrollment. Healthy controls were recruited from CSMC employees or spouses of patients with AS. Healthy controls were 18 years of age or older, supplied written consent, and were free from any history of rheumatic disease or IBD. AS patients and controls with a personal or family history of IBD were excluded from the study. AS patients undergoing treatment with mAbs against TNF $\alpha$ were either not invited to participate or were later excluded. Patients undergoing treatment with a soluble TNF $\alpha$ receptor (Enbrel; Etanercept; manufactured by Immunex Corporation, Thousand Oaks, CA 91320. Marketed by Amgen Inc., Thousand Oaks, CA 91320 and Pfizer Inc. USA) were allowed to participate. Patients and controls using NSAIDs within 2 days of the stool collection were excluded. The study was approved by the CSMC Institutional Review Board.

\section{Laboratory methods \\ Stool samples}

All participants collected stool samples at home or provided a sample during study visits. Stool samples were handled according to manufacturer recommendations (Genova Diagnostics, Asheville, NC, USA) and were frozen within 48 hours at $-20^{\circ} \mathrm{C}$. Samples were coded and sent to Genova Diagnostics for analysis.

\section{Serum samples}

All serum samples were collected during the study visit at CSMC. Sera were tested by ELISA for the IBD-related serologies: antineutrophil cytoplasmic antibodies (ANCA), ASCA IgG and IgA, anti-I2, anti-OmpC, and anti-CBir1. Serologies were all estimated by ELISA at the same time in an effort to decrease variance. The basic laboratory methods for the determination of each serology have been described previously $[31,32]$. The results of each assay are expressed in ELISA units.

\section{Additional measures}

The Bath Ankylosing Spondylitis Disease Activity Index (BASDAI), the Bath Ankylosing Spondylitis Functional Index (BASFI), and the Bath Ankylosing Spondylitis Radiology Index (BASRI) instruments were completed for AS patients in addition to an assessment of peripheral arthritis. 


\section{Statistical methods}

ASCA results were log-transformed prior to quartile distribution. The mean age and disease duration between fCAL-positive and fCAL-negative AS patients were analyzed using Student's $t$ test. The exact Fisher two-sided test was performed to compare positivity rates for fCALpositive versus fCAL-negative AS patients. The MannWhitney $U$ test was performed to compare the median values for fCAL, BASDAI score, BASRI score, and quantitative antibody levels between AS patients and healthy controls.

\section{Results}

Calprotectin samples were initially collected from 47 AS patients and 42 healthy controls. Seven AS patients were excluded from further analysis for use of prohibited NSAIDs within 48 hours of the stool collection, and one AS patient was excluded for treatment with TNF $\alpha \mathrm{mAb}$ prior to the study visit, thereby yielding a total of 81 study participants with data suitable for analysis. Demographic data for AS patients and controls are reported in Table 1. The average age of the AS patients was 47 years and the average disease duration was 22 years. AS patients were predominantly male and 76\% were HLA-B27-positive.

Positivity rates and fCAL levels are reported in Table 2. The median fCAL levels were $42 \mu \mathrm{g} / \mathrm{g}$ and $17 \mu \mathrm{g} / \mathrm{g}$ in the AS group and controls, respectively $(P=0.0002)$. When using the manufacturer's recommended cutoff value for positivity of $50 \mu \mathrm{g} / \mathrm{g}$, stool samples of $41 \%$ of AS patients and $10 \%$ of controls were positive for fCAL $(P=0.0016)$.

Calprotectin levels for AS patients and controls are displayed in Figure 1. In general, the fCal levels of AS patients are higher than the fCAL levels of controls. The highest measured level of fCAL in the control group was $104 \mu \mathrm{g} / \mathrm{g}$, while the highest observed level in the AS group was 1,085 $\mu \mathrm{g} / \mathrm{g}$. Demographic and clinical parameters of AS subjects stratified by fCAL positivity are shown in Tables 3 and 4 . There were no significant differences between the fCALpositive and fCAL-negative AS patients with regards to age, gender, ethnicity, disease duration and HLA-B27 positivity. There was also no significant difference in NSAID use or Enbrel use (Table 4). Although the median BASFI in the fCAL-positive group was 41.6, compared with 17 in the fCAL-negative group, this association was not statistically significant. There was no significant difference for the BASRI or the occurrence of peripheral arthritis between these two groups of AS patients (Table 4).

With the exception of ANCA, there were no significant differences in antibody levels between patients and controls (Table 5). The median ANCA value was 6.9 ELISA units in AS patients and 4.3 ELISA units in the controls $(P=0.003)$. At the fCAL threshold of $50 \mu \mathrm{g} / \mathrm{g}$, there were statistically significant differences between AS fCAL-positive patients and controls $(P<0.05)$ for ANCA, ASCA IgG, and anti-CBir 1 antibodies (9.2 vs. $4.3,11.5$ vs. 6.7 , and 27.2 vs. 15.9 , respectively). There was no statistically significant difference between the AS fCAL-negative patients compared with the healthy controls (Table 6).

When fCAL-positive AS patients were compared with fCAL-negative AS patients at the $50 \mu \mathrm{g} / \mathrm{g}$ threshold, significant differences were found in IgA ASCA levels $(P=$ $0.05)$, IgG ASCA levels $(P=0.003)$, and Cbir1 $(P=0.002$; Table 7). A trend towards significant association was seen in ANCA levels $(P=0.06$; Table 7$)$.

\section{Discussion}

In this exploratory study, we report a higher prevalence and increased levels of fCAL positivity as well as an association with the IBD serological markers ANCA, ASCA, antiCBir1, anti-I2 and anti-OmpC antibodies in a well-characterized cohort of AS patients. The fCAL-positive AS patients in our study displayed higher medians of most IBD-specific antibodies when compared with healthy controls or fCAL-negative AS patients. Our finding of $41 \%$ of patients with $\mathrm{fCAL}>50 \mu \mathrm{g} / \mathrm{g}$ is considerably lower than the $68 \%$ of patients with fCAL > $50 \mathrm{mg} / \mathrm{kg}$ found by Klingberg and colleagues [33]. However, the latter group contained AS subjects taking all of the usual clinically indicated medications, including NSAIDs and anti-TNF agents. In addition, in a small study of enthesitis-related arthritis in children - a condition felt to be a form of pediatric spondyloarthritis that is typically HLA B-29-positive - fCAL was

Table 1 Demographic data for ankylosing spondylitis patients and healthy controls

\begin{tabular}{lll}
\hline & Ankylosing spondylitis patients $(\boldsymbol{n}=\mathbf{3 9})$ & Healthy controls $(\boldsymbol{n}=\mathbf{4 2})$ \\
\hline Age (years) & $47(20$ to 85$)$ & $39(27$ to 70$)$ \\
Male & 82 & 52 \\
HLA-B27 & 76 & Not available \\
Disease duration (years) & $22(2$ to 62) & Not applicable \\
Ethnicity & & 54 \\
$\quad$ Caucasian & 77 & 36 \\
$\quad$ Asian & 8 & 10
\end{tabular}

Data presented as mean (range) or percentage. 
Table 2 Positivity rates and level of fecal calprotectin in ankylosing spondylitis patients and healthy controls

\begin{tabular}{llll}
\hline & Ankylosing spondylitis patients $(\boldsymbol{n}=\mathbf{3 9})$ & Healthy controls $(\boldsymbol{n}=\mathbf{4 2})$ & $\boldsymbol{P}$ value \\
\hline Fecal calprotectin $(\mu \mathrm{g} / \mathrm{g})$ & $42(16$ to 1,085) & $17(16$ to 104$)$ & 0.0002 \\
Fecal calprotectin positive $($ positive $>50 \mu \mathrm{g} / \mathrm{g})$ & $16(41 \%)$ & $4(10 \%)$ & 0.0016 \\
\hline
\end{tabular}

Data presented as mean (range) or number (percentage).

shown to be a distinguishing feature for this form of juvenile idiopathic arthritis compared with other pediatric rheumatologic conditions and controls [34].

The relationship between AS and IBD has been under study in recent years. Increased gut permeability and inflammation in AS has been observed in multiple studies; however, the range of gut prevalence varies by the type of method used to assess inflammation. Invasive methods such as colonoscopies and biopsies have shown macroscopic and microscopic gut inflammation in 25 to $60 \%$ of AS patients while noninvasive observational studies report clinical overt IBD in 5 to $10 \%$ of AS patients (as reviewed in [35]). Our study is intended to evaluate a practical approach for further studies that will bridge the gap between invasive methodologies to determine prevalence

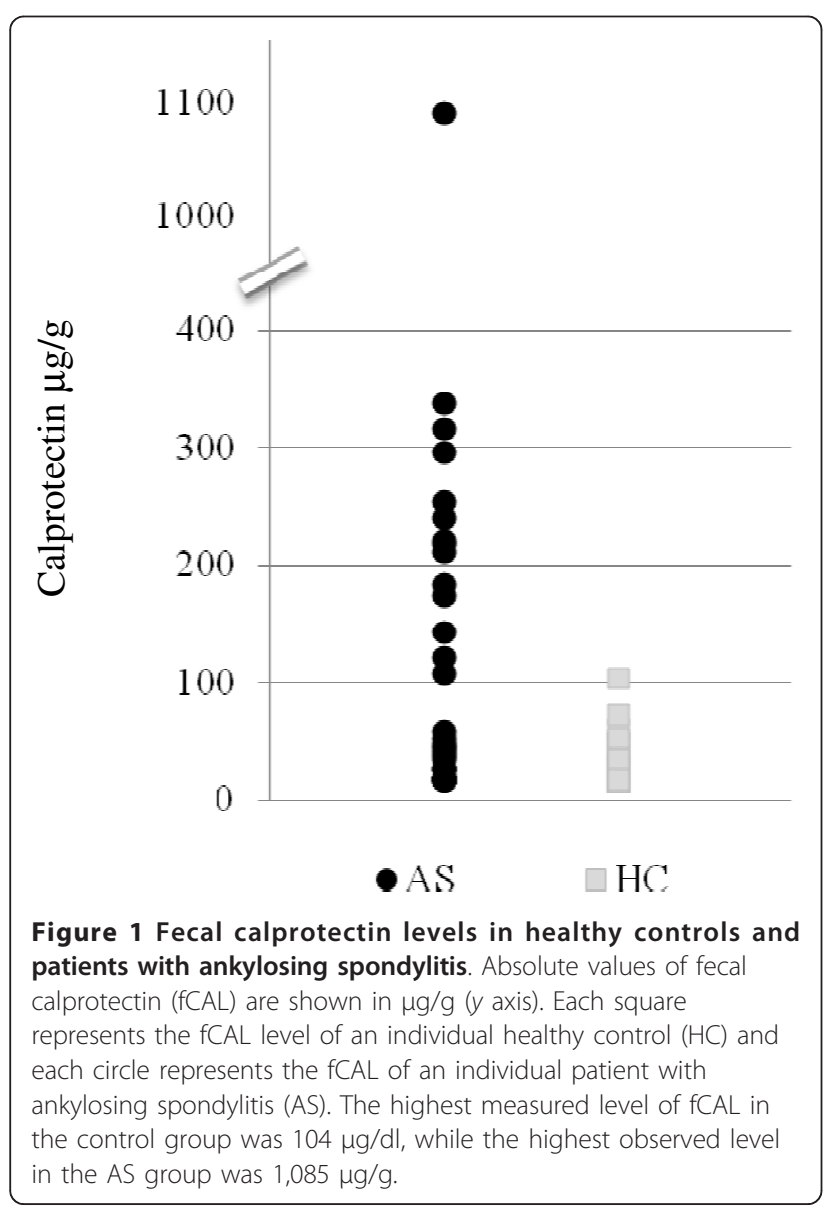

of gut inflammation in AS and the less sensitive methods utilizing clinical histories and symptoms.

Although attempts have been made in the recent past to utilize biomarkers of gut inflammation in similar investigations such as ours, many of these studies have not controlled adequately for medications that can influence gut inflammation such as TNF $\alpha$ inhibitors or NSAIDs. We attempted to address this potential limitation using strict inclusion and exclusion criteria. mAbs against TNF $\alpha$ (infliximab, adalimumab and certolizumab pegol) have proven efficacy in IBD and are US Food and Drug Administration approved to treat IBD [36-39]. Etanercept, a $\mathrm{TNF} \alpha$ receptor fusion protein, has not been shown to be efficacious in IBD but is widely used for AS [40]. We limited our patient study population to allow etanercept only. Further, NSAIDs have been shown to increase gut permeability and inflammation in healthy users [41]. The literature is unclear regarding how long the effects on the intestinal mucosa caused by NSAIDs will last. The manufacturer of the fCAL assay used in this study (Genova Diagnostics) recommends avoiding NSAIDs within 48 hours of collection. Adhering to this recommendation, we observed $41 \%$ of AS patients to display positive fCAL levels (fCAL > $50 \mu \mathrm{g} / \mathrm{g}$ ). When all AS patients that used NSAIDS on a regular basis were excluded, the percentage of fCAL-positive patients changed only marginally (data not shown).

The increase of fCAL seen in the stool of IBD patients has been shown to be a direct result of increased neutrophil migration into the gut lumen across inflamed mucosa [26], and in subjects with IBD the levels of fCAL correlate with the endoscopic and histological degree of gut inflammation in adults and children [27]. A recent meta-analysis reported a sensitivity of 0.95 and a specificity of 0.91 for fCAL to diagnose IBD in adults. The diagnostic precision of fCAL had a better accuracy at a cutoff level of $100 \mu \mathrm{g} / \mathrm{g}$ versus $50 \mu \mathrm{g} / \mathrm{g}$ [42].

Interestingly, BASFI and BASDAI scores are higher for fCAL-positive patients compared with fCAL-negative AS patients. This finding might suggest more disease activity and functional disability in the group of patients with subclinical inflammation of the gut. Prior studies have found higher BASFI scores in ASCA-positive AS patients, confirming our findings [23]. There are two possible explanations for this observation. First, subclinical gut inflammation might lead to increased gut permeability and prolonged antigen exposure, triggering more severe 
Table 3 Demographic data for ankylosing spondylitis patients stratified by fecal calprotectin positivity

\begin{tabular}{llll}
\hline & Fecal calprotectin cutoff $\mathbf{5 0} \boldsymbol{\mu} \mathbf{g} \mathbf{g}$ & & \\
\cline { 2 - 4 } & Fecal calprotectin positive $(\boldsymbol{n}=\mathbf{1 6})$ & Fecal calprotectin negative $(\boldsymbol{n}=\mathbf{2 3})$ & $\boldsymbol{P}$ value \\
\hline Mean age (years) & 45 & 49 & 0.48 \\
Male, $\boldsymbol{n}$ (\%) & $14(88)$ & $18(78)$ & 0.68 \\
HLA-B27-positive, $n$ (\%) & $11(69)$ & $18(82)$ & 0.71 \\
Mean disease duration (years) & 22 & 22 & 0.96 \\
Ethnicity (\%) & 8 & 74 & 0.71 \\
$\quad$ Caucasian & 0 & 13 & 0.26 \\
$\quad$ Asian & 19 & 13 & 0.67 \\
\hline
\end{tabular}

disease as evidenced by higher BASDAI scores and more functional disability as evidenced by higher BASFI scores. The second possibility is that patients with higher BASDAI and BASFI scores have higher levels of gut inflammation due to more severe disease. Our sample numbers are too small to make any of these distinctions, however, and further studies are needed to confirm this interesting finding.

Analysis of serologies revealed that there were no significant differences between controls and fCAL-negative AS patients. However, when fCAL-positive AS patients were compared with fCAL-negative AS patients and controls, a significantly higher median was found for some of the IBD-specific antibodies. Calprotectin-positive AS patients compared with controls have significantly higher mean values for antibodies against OmpC, CBir1, and ANCAs, ASCA IgG and IgA. When fCAL-positive AS patients are compared with fCAL-negative AS patients, these findings are confirmed for antibodies against CBir1 and ASCA IgG and IgA, but not for antibodies against ANCA, OmpC or I2 (although trends towards significant association are seen with ANCA and OmpC). These results suggest that the fCAL-positive AS patient might have prolonged antigenic exposure to gut antigens as evidenced by the development of serologic memory. In addition, results in fCAL-positive AS patients suggest the importance of a potential bacterial trigger that could provide a link to new genetic discoveries. Our most recent findings that polymorphisms of ERAP1, which encode an endoplasmic reticulum aminopeptidase involved in peptide trimming before HLA class I presentation, only affects AS risk in HLA-B27-positive individuals provides strong evidence that HLA-B27 operates in AS through a mechanism involving aberrant processing of antigenic peptides [43].

There are important limitations to interpreting the results from this study. First, our sample size is small and a larger study is required to more precisely determine the prevalence of subclinical bowel inflammation in our own patient cohort. Our study is cross-sectional; longitudinal studies will be needed to determine the clinical significance of fCAL and IBD-specific serologies in AS. Second, although our patients were not taking NSAIDs for at least 48 hours prior to the study, there could be a carryover effect or patients may not have been compliant with the instructions. Third, we do not have concurrent colonoscopies or capsule studies of our AS patients that might confirm whether fCAL positivity truly correlates with bowel inflammation. However, fCAL testing has an excellent

Table 4 Clinical data for ankylosing spondylitis patients in stratified by fecal calprotectin positivity

\begin{tabular}{|c|c|c|c|}
\hline & \multicolumn{3}{|l|}{ Fecal calprotectin cutoff $50 \mu \mathrm{g} / \mathrm{g}$} \\
\hline & Fecal calprotectin positive $(n=16)$ & Fecal calprotectin negative $(n=23)$ & $P$ value \\
\hline NSAID use & $6(38 \%)$ & $10(43 \%)$ & 0.75 \\
\hline Enbrel use & $9(56 \%)$ & $8(35 \%)$ & 0.20 \\
\hline Patients waking up at night for bowel movement & $3(19 \%)$ & $3(13 \%)$ & 0.67 \\
\hline BASDAI score & $3.0(0.1$ to 7.75$)$ & $1.8(0.03$ to 7.66$)$ & 0.16 \\
\hline BASRI score & $6.0(2$ to 13.5$)$ & $5.0(2$ to 11$)$ & 0.64 \\
\hline BASFI score & $41.6(0.4$ to 92.5$)$ & 17.1 (0 to 72.1$)$ & 0.09 \\
\hline Erythrocyte sedimentation rate & $8.5(0$ to 62$)$ & 17 (2 to 64) & 0.75 \\
\hline C-reactive protein & $0.44(0.03$ to 5.7$)$ & 0.57 (0.02 to 4.84$)$ & 0.58 \\
\hline Patients with history of uveitis & $7(44 \%)$ & $10(43 \%)$ & 1.0 \\
\hline Patients with history of peripheral arthritis in the knee & $4(25 \%)$ & $5(22 \%)$ & 1.0 \\
\hline Patients with history of peripheral arthritis in the ankle & $5(31 \%)$ & $4(17 \%)$ & 0.44 \\
\hline
\end{tabular}

Data presented as median (range) or number (percentage). BASDAl, Bath ankylosing spondylitis disease activity index; BASFI, Bath ankylosing spondylitis functional index; BASRI, Bath ankylosing spondylitis radiology index. 
Table 5 Serologies of ankylosing spondylitis patients and healthy controls

\begin{tabular}{llll}
\hline & \multicolumn{2}{l}{ Healthy controls (all) versus AS patients (all) } & $\boldsymbol{P}$ value \\
\cline { 2 - 4 } & Median healthy controls (all) & Median AS patients (all) & 0.737 \\
\hline IgA ASCA (ELISA units) & 0.4 & 0.5 & 0.597 \\
IgG ASCA (ELISA units) & 6.7 & 6.6 & 0.685 \\
I2 (ELISA units) & 5.7 & 6 & 0.473 \\
OmpC (ELISA units) & 5.7 & 6.4 & 0.223 \\
Cbir1 Fla (ELISA units) & 15.9 & 19.8 & 0.003 \\
ANCA (ELISA units) & 4.3 & 6.9 & \\
\hline
\end{tabular}

ANCA, antineutrophil cytoplasmic antibodies; AS, ankylosing spondylitis; ASCA, anti-Saccharomyces cerevisiae antibody; CBir1, anti-flagellin; OmpC, anti-Escherichia coli outer membrane porin $C$.

Table 6 Serologies of ankylosing spondylitis patients and healthy controls stratified by fecal calprotectin

\begin{tabular}{|c|c|c|c|c|c|}
\hline & \multicolumn{5}{|c|}{ Healthy controls (all) compared with AS patients (fCAL cutoff $50 \mu \mathrm{g} / \mathrm{g}$ ) } \\
\hline & $\begin{array}{l}\text { Median } \\
\text { HC }\end{array}$ & $\begin{array}{l}\text { Median AS fCAL- } \\
\text { negative }\end{array}$ & $\begin{array}{l}P \text { value (HC versus fCAL- } \\
\text { negative) }\end{array}$ & $\begin{array}{l}\text { Median AS fCAL- } \\
\text { positive }\end{array}$ & $\begin{array}{l}P \text { value (HC versus fCAL- } \\
\text { positive) }\end{array}$ \\
\hline $\begin{array}{l}\text { IgA ASCA (ELISA } \\
\text { units) }\end{array}$ & 0.4 & 0.2 & 0.478 & 1.9 & 0.110 \\
\hline $\begin{array}{l}\lg G \text { ASCA (ELISA } \\
\text { units) }\end{array}$ & 6.7 & 6.2 & 0.344 & 11.5 & 0.023 \\
\hline 12 (ELISA units) & 5.7 & 6.8 & 0.394 & 4 & 0.703 \\
\hline OmpC (ELISA units) & 5.7 & 6.1 & 0.904 & 8.4 & 0.240 \\
\hline $\begin{array}{l}\text { Cbir1 Fla (ELISA } \\
\text { units) }\end{array}$ & 15.9 & 16.2 & 0.659 & 27.2 & 0.003 \\
\hline ANCA (ELISA units) & 4.3 & 5 & 0.240 & 9.2 & $<0.001$ \\
\hline
\end{tabular}

ANCA, antineutrophil cytoplasmic antibodies; AS, ankylosing spondylitis; ASCA, anti-Saccharomyces cerevisiae antibody; CBir1, anti-flagellin; fCAL, fecal calprotectin; $\mathrm{HC}$, healthy controls; OmpC, anti-Escherichia coli outer membrane porin C.

Table 7 Serologies of patients with ankylosing spondylitis stratified by fecal calprotectin

\begin{tabular}{llll}
\hline & \multicolumn{1}{l}{ AS fCAL-positive versus fCAL-negative (cutoff $\mathbf{5 0} \boldsymbol{\mu} \mathbf{g} \mathbf{g}$ ) } \\
\cline { 2 - 4 } & Median AS fCAL-positive & Median AS fCAL-negative & $P$ value \\
\hline IgA ASCA (ELISA units) & 1.9 & 0.2 & 0.05 \\
IgG ASCA (ELISA units) & 11.5 & 6.2 & 0.003 \\
I2 (ELISA units) & 4 & 6.8 & 0.36 \\
OmpC (ELISA units) & 8.4 & 6.1 & 0.34 \\
Cbir1 Fla (ELISA units) & 27.2 & 16.2 & 0.002 \\
ANCA (ELISA units) & 9.2 & 5 & 0.06 \\
\hline
\end{tabular}

ANCA, antineutrophil cytoplasmic antibodies; AS, ankylosing spondylitis; ASCA, anti-Saccharomyces cerevisiae antibody; CBir1, anti-flagellin; fCAL, fecal calprotectin; OmpC, anti-Escherichia coli outer membrane porin C.

specificity and sensitivity in distinguishing IBD from nonIBD. Further studies of these relationships will serve to place patients in a clinical context and to provide associations with clinical characteristics, disease severity, and treatment response. Our preliminary data suggest that fCAL-positive AS patients have more active disease, a finding with significant clinical implications if verified in other studies.

\section{Conclusion}

In summary, fCAL, a fecal marker for whole gut inflammation, as well as serological antibodies that have been well studied and characterized in IBD are found in a higher percentage of AS patients followed at our institution compared with healthy controls. Further studies, including more patients on a variety of medications, and longitudinal observations will be needed to prospectively determine whether fCAL can be used to identify and characterize a subgroup of AS patients whose disease might be driven by subclinical bowel inflammation.

\section{Abbreviations}

ANCA: antineutrophil cytoplasmic antibodies; AS: ankylosing spondylitis; ASCA: anti-Saccharomyces cerevisiae antibody; BASDAl: Bath ankylosing spondylitis disease activity index; BASFl: Bath ankylosing spondylitis functional index; BASRl: Bath ankylosing spondylitis radiology index; CBir1: anti-flagellin; CSMC: Cedars-Sinai Medical Center; ELISA: enzyme-linked 
immunosorbent assay; fCAL: fecal calprotectin; HLA: human leukocyte antigen; IBD: inflammatory bowel disease; IL: interleukin; mAb: monoclonal antibody; NSAID: nonsteroidal anti-inflammatory drug; OmpC: anti-Escherichia coli outer membrane porin C; Th: T-helper type; TNF: tumor necrosis factor.

\section{Acknowledgements}

We would like to acknowledge Franziska G. Matzkies's scholarship: ACR REF/ Ephraim P. Engleman Endowed Resident Research Preceptorship. The project described was also supported by the National Center for Research Resources, Grant UL1RR033176, and is now at the National Center for Advancing Translational Sciences, Grant UL1TR000124. The content is solely the responsibility of the authors and does not necessarily represent the official views of the $\mathrm{NIH}$.

\section{Author details}

${ }^{1}$ Department of Medicine, Division of Rheumatology, University of California, San Francisco, 533 Parnassus Avenue, Room U384/ Box 0633, San Francisco, CA 94143, USA. ${ }^{2}$ Inflammatory Bowel and Immunobiology Research Institute, Cedars-Sinai Medical Center, 8700 Beverly Boulevard, Los Angeles, CA 90048, USA. ${ }^{3}$ Division of Rheumatology, University of Texas, 6410 Fannin Street, Houston, TX 77030, USA. ${ }^{4}$ Medical Genetics Institute, Cedars-Sinai Medical Center, 8700 Beverly Boulevard, Los Angeles, CA 90048, USA. ${ }^{5}$ Division of Rheumatology, Cedars-Sinai Medical Center, 8700 Beverly Boulevard, Becker B-131, Los Angeles, CA 90048, USA.

\section{Authors' contributions}

FGM designed the project, collected data, analyzed data, and wrote the manuscript draft. SRT designed the project, analyzed data, and edited the manuscript. DB designed the analytic plan and provided statistical support and analysis consultancy. CJL analyzed serologic data. DPBM designed the project, analyzed data, and edited the manuscript. MHW designed the study, recruited research subjects, supervised data collection, analyzed data, and edited the manuscript. JDR helped design the project and helped analyze data. All authors read and approved the final manuscript.

\section{Competing interests}

The authors declare that they have no competing interests.

Received: 20 June 2012 Revised: 24 September 2012

Accepted: 29 October 2012 Published: 29 November 2012

\section{References}

1. Van Praet L, Van den Bosch F, Mielants H, Elewaut D: Mucosal inflammation in spondylarthritides: past, present, and future. Curr Rheumatol Rep 2011, 13:409-415.

2. Rosenbaum J, Chandran V: Management of comorbidities in ankylosing spondylitis. Am J Med Sci 2012, 343:364-366.

3. De Keyser F, Elewaut D, De Vos M, De Vlam K, Cuvelier C, Mielants H, Veys EM: Bowel inflammation and the spondyloarthropathies. Rheum Dis Clin North Am 1998, 24:785-813, ix-x.

4. Leirisalo-Repo M, Turunen U, Stenman S, Helenius P, Seppala K: High frequency of silent inflammatory bowel disease in spondylarthropathy. Arthritis Rheum 1994, 37:23-31.

5. Mielants H, Veys EM, Cuvelier C, de Vos M: lleocolonoscopic findings in seronegative spondylarthropathies. Br J Rheumatol 1988, 27(Suppl 2):95-105.

6. Mielants H, Veys EM, Cuvelier C, De Vos M, Goemaere S, De Clercq L, Schatteman L, Elewaut D: The evolution of spondyloarthropathies in relation to gut histology. II. Histological aspects. J Rheumatol 1995, 22:2273-2278.

7. Mielants H, Veys EM, Cuvelier C, De Vos M, Goemaere S, De Clercq L, Schatteman L, Gyselbrecht L, Elewaut D: The evolution of spondyloarthropathies in relation to gut histology. III. Relation between gut and joint. J Rheumatol 1995, 22:2279-2284.

8. Mielants H, Bosch F: Inflammatory bowel disease spondyloarthritis: epidemiology, clinical features, and treatment. In Ankylosing Spondylitis and the Spondlyoarthropathies.. 1 edition. Edited by: Weisman $\mathrm{MH}$, Reveille JD, van der Heijde D. Philadelphia, PA: Mosby; 2006:

9. Barrett JC, Hansoul S, Nicolae DL, Cho JH, Duerr RH, Rioux JD, Brant SR, Silverberg MS, Taylor KD, Barmada MM, Bitton A, Dassopoulos T, Gatta LW, Green T, Griffiths AM, Kistner EO, Murtha MT, Requeiro MD, Rotter JI,
Schumm LP, Steinhart AH, Targan SR, Xavier RJ, NIDDK IBD Genetics Consortium, Libioulle C, Sandor C, Lathrop M, Belaiche J, Dewit O, Gut I, Heath $S$, et al: Genome-wide association defines more than 30 distinct susceptibility loci for Crohn's disease. Nat Genet 2008, 40:955-962.

10. Franke A, McGovern DP, Barrett JC, Wang K, Radford-Smith GL, Ahmad T, Lees CW, Balschun T, Lee J, Roberts R, Anderson CA, Bis JC, Bumpstead S, Ellinghaus D, Festen EM, Georges $M$, Green $T$, Haritunians $T$, Jostins $L$, Latiano A, Matthew CG, Montgomery GW, Prescott NJ, Raychaudhuri S, Rotter Jl, Schumm P, Sharma Y, Simms LA, Taylor KD, Whiteman D, et al: Genome-wide meta-analysis increases to 71 the number of confirmed Crohn's disease susceptibility loci. Nat Genet 2010, 42:1118-1125.

11. Anderson CA, Boucher G, Lees CW, Franke A, D'Amato M, Taylor KD, Lee JC, Goyette P, Imielinski M, Latiano A, Legacé C, Scott R, Amininejad L, Bumpstead S, Baidoo L, Baldassano RN, Barclay M, Bayless TM, Brand S, Büning C, Colombel JF, Denson LA, De Vos M, Dubinsky M, Edwards C, Ellinghaus D, Fehrmann RS, Floyd JA, Florin T, Franchimont D, et al: Metaanalysis identifies 29 additional ulcerative colitis risk loci, increasing the number of confirmed associations to 47. Nat Genet 2011, 43:246-252.

12. Franke $A$, Balschun $T$, Sina $C$, Ellinghaus $D$, Häsler R, Mayr G, Albrecht M, Wittig M, Buchert E, Nikolaus S, Gieger C, Wichmann HE, Sventoraityte J, Kupcinskas L, Onnie CM, Gazouli M, Anagnou NP, Strachan D, McArdle WL, Mathew CG, Rutgeerts $P$, Vermeire $S$, Vatn MH, IBSEN Study Group, Krawczak M, Rosenstiel P, Karlsen TH, Schreiber S: Genome-wide association study for ulcerative colitis identifies risk loci at 7q22 and 22q13 (IL17REL). Nat Genet 2010, 42:292-294.

13. Yamazaki K, McGovern D, Ragoussis J, Paolucci M, Butler $H$, Jewell D, Cardon L, Takazoe M, Tanaka T, Ichimori T, Saito S, Sekine A, lida A, Takahashi A, Tsunoda T, Lathrop M, Nakamura Y: Single nucleotide polymorphisms in TNFSF15 confer susceptibility to Crohn's disease. Hum Mol Genet 2005, 14:3499-3506.

14. Thjodleifsson B, Geirsson AJ, Bjornsson S, Bjarnason I: A common genetic background for inflammatory bowel disease and ankylosing spondylitis: a genealogic study in Iceland. Arthritis Rheum 2007, 56:2633-2639.

15. Taurog JD: The role of HLA-B27 in spondyloarthritis. J Rheumatol 2010 37:2606-2616.

16. Salvarani C, Fries W: Clinical features and epidemiology of spondyloarthritides associated with inflammatory bowel disease. World J Gastroenterol 2009, 15:2449-2455.

17. Jacques $P$, Elewaut $D$, Mielants $H$ : Interactions between gut inflammation and arthritis/spondylitis. Curr Opin Rheumatol 2010, 22:368-374.

18. Danoy P, Pryce K, Hadler J, Bradbury LA, Farrar C, Pointon J, Australo-AngloAmerican Spondyloarthritis Consortium, Ward M, Weisman M, Reveille JD, Wordsworth BP, Stone MA, Spondyloarthritis Research Consortium of Canada, Maksymowych WP, Rahman P, Gladman D, Inman RD, Brown MA: Association of variants at $1 \mathrm{q} 32$ and STAT3 with ankylosing spondylitis suggests genetic overlap with Crohn's disease. PLoS Genet 2010, 6: e1001195.

19. Martinez-Gonzalez O, Cantero-Hinojosa J, Paule-Sastre P, Gomez-Magan JC, Salvatierra-Rios D: Intestinal permeability in patients with ankylosing spondylitis and their healthy relatives. Br J Rheumato/ 1994, 33:644-647.

20. Quinton JF, Sendid B, Reumaux D, Duthilleul P, Cortot A, Grandbastien B, Charrier G, Targan SR, Colombel JF, Poulain D: Anti-Saccharomyces cerevisiae mannan antibodies combined with antineutrophil cytoplasmic autoantibodies in inflammatory bowel disease: prevalence and diagnostic role. Gut 1998, 42:788-791.

21. Targan SR, Landers CJ, Yang H, Lodes MJ, Cong Y, Papadakis KA, Vasiliauskas E, Elson CO, Hershberg RM: Antibodies to CBir1 flagellin define a unique response that is associated independently with complicated Crohn's disease. Gastroenterology 2005, 128:2020-2028.

22. Mundwiler ML, Mei L, Landers CJ, Reveille JD, Targan S, Weisman MH: Inflammatory bowel disease serologies in ankylosing spondylitis patients: a pilot study. Arthritis Res Ther 2009, 11:R177.

23. Aydin SZ, Atagunduz P, Temel M, Bicakcigil M, Tasan D, Direskeneli H: AntiSaccharomyces cerevisiae antibodies (ASCA) in spondyloarthropathies: a reassessment. Rheumatology (Oxford) 2008, 47:142-144

24. Torok HP, Glas J, Gruber R, Brumberger V, Strasser C, Kellner H, MarkerHermann E, Folwaczny C: Inflammatory bowel disease-specific autoantibodies in HLA-B27-associated spondyloarthropathies: increased prevalence of ASCA and pANCA. Digestion 2004, 70:49-54.

25. Riente L, Chimenti D, Pratesi F, Delle Sedie A, Tommasi S, Tommasi C, Bombardieri S, Migliorini P: Antibodies to tissue transglutaminase and 
Saccharomyces cerevisiae in ankylosing spondylitis and psoriatic arthritis. J Rheumatol 2004, 31:920-924.

26. Konikoff MR, Denson LA: Role of fecal calprotectin as a biomarker of intestinal inflammation in inflammatory bowel disease. Inflammatory Bowel Dis 2006, 12:524-534.

27. Tibble J, Teahon K, Thjodleifsson B, Roseth A, Sigthorsson G, Bridger S, Foster R, Sherwood R, Fagerhol M, Bjarnason I: A simple method for assessing intestinal inflammation in Crohn's disease. Gut 2000, 47:506-513.

28. Bunn SK, Bisset WM, Main MJ, Golden BE: Fecal calprotectin as a measure of disease activity in childhood inflammatory bowel disease. J Pediatr Gastroenterol Nutr 2001, 32:171-177.

29. Lee W, Reveille JD, Davis JC Jr, Learch TJ, Ward MM, Weisman MH: Are there gender differences in severity of ankylosing spondylitis? Results from the PSOAS cohort. Ann Rheum Dis 2007, 66:633-638.

30. van der Linden S, Valkenburg HA, Cats A: Evaluation of diagnostic criteria for ankylosing spondylitis. A proposal for modification of the New York criteria. Arthritis Rheum 1984, 27:361-368.

31. Landers CJ, Cohavy O, Misra R, Yang H, Lin YC, Braun J, Targan SR: Selected loss of tolerance evidenced by Crohn's disease-associated immune responses to auto- and microbial antigens. Gastroenterology 2002, 123:689-699.

32. Papadakis KA, Yang H, Ippoliti A, Mei L, Elson CO, Hershberg RM, Vasiliauskas EA, Fleshner PR, Abreu MT, Taylor K, Landers CJ, Rotter Jl, Targan SR: Anti-flagellin (CBir1) phenotypic and genetic Crohn's disease associations. Inflammatory Bowel Dis 2007, 13:524-530.

33. Klingberg E, Carlsten H, Hilme E, Hedberg M, Forsblad-d'Elia H: Calprotectin in ankylosing spondylitis - frequently elevated in feces, but normal in serum. Scand J Gastroenterol 2012, 47:435-444.

34. Stoll ML, Punaro M, Patel AS: Fecal calprotectin in children with the enthesitis-related arthritis subtype of juvenile idiopathic arthritis. J Rheumatol 2011, 38:2274-2275.

35. Rudwaleit M, Baeten D: Ankylosing spondylitis and bowel disease. Best Pract Res Clin Rheumatol 2006, 20:451-471.

36. Targan SR, Hanauer SB, van Deventer SJ, Mayer L, Present DH, Braakman T, DeWoody KL, Schaible TF, Rutgeerts PJ: A short-term study of chimeric monoclonal antibody CA2 to tumor necrosis factor alpha for Crohn's disease. Crohn's Disease cA2 Study Group. N Engl J Med 1997, 337:1029-1035.

37. Present DH, Rutgeerts P, Targan S, Hanauer SB, Mayer L, van Hogezand RA, Podolsky DK, Sands BE, Braakman T, DeWoody KL, Schaible TF, van Deventer SJ: Infliximab for the treatment of fistulas in patients with Crohn's disease. N Engl J Med 1999, 340:1398-1405.

38. Baert FJ, D'Haens GR, Peeters M, Hiele MI, Schaible TF, Shealy D, Geboes K, Rutgeerts PJ: Tumor necrosis factor alpha antibody (infliximab) therapy profoundly down-regulates the inflammation in Crohn's ileocolitis. Gastroenterology 1999, 116:22-28.

39. Rutgeerts P, Sandborn WJ, Feagan BG, Reinisch W, Olson A, Johanns J, Travers S, Rachmilewitz D, Hanauer SB, Licentenstein GR, de Villiers WJ, Present D, Sands BE, Colombel JF: A randomized placebo-controlled trial of infliximab for active ulcerative colitis: the ACT I trial. Gastroenterology 2005, 128(Suppl 2):A105.

40. Marzo-Ortega H, McGonagle D, O'Connor P, Emery P: Efficacy of etanercept for treatment of Crohn's related spondyloarthritis but not colitis. Ann Rheum Dis 2003, 62:74-76.

41. Higuchi K, Umegaki E, Watanabe T, Yoda Y, Morita E, Murano M, Tokioka S, Arakawa T: Present status and strategy of NSAIDs-induced small bowel injury. J Gastroenterol 2009, 44:879-888.

42. von Roon AC, Karamountzos L, Purkayastha S, Reese GE, Darzi AW, Teare JP, Paraskeva P, Tekkis PP: Diagnostic precision of fecal calprotectin for inflammatory bowel disease and colorectal malignancy. Am J Gastroenterol 2007, 102:803-813.

43. Evans DM, Spencer CC, Pointon JJ, Su Z, Harvey D, Kochan G, Oppermann U, Dilthey A, Pirinen M, Stone MA, Appleton L, Moutsianas L, Leslie S, Wordsworth T, Kenna TJ, Karaderi T, Thomas GP, Ward MM, Weisman MH, Farrar C, Bradbury LA, Danoy P, Inman RD, Maksymowych W, Gladman D, Rahman P, Spondyloarthritis Research Consortium of Canada, Morgan A, Marzo-Ortega H, Bowness P, et al: Interaction between ERAP1 and HLA-B27 in ankylosing spondylitis implicates peptide handling in the mechanism for HLA-B27 in disease susceptibility. Nat Genet 2011, 43:761-767.

\section{doi:10.1186/ar4106}

Cite this article as: Matzkies et al:: Markers of intestinal inflammation in patients with ankylosing spondylitis: a pilot study. Arthritis Research \& Therapy 2012 14:R261.

\section{Submit your next manuscript to BioMed Central and take full advantage of:}

- Convenient online submission

- Thorough peer review

- No space constraints or color figure charges

- Immediate publication on acceptance

- Inclusion in PubMed, CAS, Scopus and Google Scholar

- Research which is freely available for redistribution

Submit your manuscript at www.biomedcentral.com/submit
Ciomed Central 